\title{
Teknologi Vertiminaponik: Solusi Agribisnis Modern
}

Tri Herbaning Tiyas Wahyu Ningrum, Alvy Ervita Cahyany, Tiara meyna Anggraini, Wachidatul Linda Yuhanna

\section{(C) 2021 JEMS (Jurnal Edukasi Matematika dan Sains)}

This is an open access article under the CC-BY-SA license

(https://creativecommons.org/licenses/by-sa/4.0/) ISSN 2337-9049 (print), ISSN 2502-4671 (online)

\begin{abstract}
Abstrak:
Peternakan lele dan pertanian hortikultura merupakan salah satu aspek vital dalam penyediaan pangan di masyarakat. Vertiminaponik adalah budidaya sayuran secara vertikal dengan sistem akuaponik, dari satu tempat yang sama dapat menghasilkan dua komoditas sekaligus yaitu sayur dan ikan lele. Tujuan dari penelitian ini adalah mengembangkan sistem vertiminaponik untuk peternal lele. Penelitian ini adalah penelitian pengembangan dengan menggunakan 4D (Define, Design, Develop dan Disseminate. Hasil dari penelitian ini adalah vertiminaponik yang dikembangkan merupakan modifikasi Teknik Film Nutrisi (NFT) menggunakan serangkaian pipa yang disusun berdekatan dengan tangki ikan. Berdasarkan penilaian validator dari unsur akademisi dan praktisi, produk vertiminaponik dalam kategori sangat baik sehingga layak dan tanpa revisi untuk diimplementasikan kepada kelompok sasaran. Teknologi vertiminaponik ini siap digunakan untuk kelompok peternak lele.
\end{abstract}

Kata Kunci : Vertiminaponik, Agribisnis, Lele, Hortikultura

\begin{abstract}
:
Catfish farming and horticultural farming is one of the vital aspects in providing food in the community. Vertiminaponics is the vertical cultivation of vegetables with an aquaponic system, from the same place it can produce two commodities at once, namely vegetables and catfish. The purpose of this study was to develop a vertiminaponic system for peternal catfish. This research is a development research using 4D (Define, Design, Develop and Disseminate. The result of this research is that the developed vertiminaponics is a modification of the Nutritional Film Technique (NFT) using a series of pipes that are arranged adjacent to the fish tank. The vertiminaponic product is in the very good category so that it is feasible and without revision to be implemented for the target group This vertiminaponic technology is ready to be used for catfish farmer groups.
\end{abstract}

Keywords : Vertiminaponics, Agribusiness, Catfish, Horticulture

\section{Pendahuluan}

Peternakan lele dan pertanian hortikultura merupakan salah satu aspek vital dalam penyediaan pangan di masyarakat. Potensi dari peternakan lele sangat baik jika dikelola dan dilakukan secara holistik baik dari segi pembudidayaan, pemasaran dan distribusinya. Proses pembudidayaan lele dapat dilakukan dengan berbagai inovasi untuk menghasilkan produk yang lebih multivariat. Sinergisitas antara akademisi dan kelompok masyarakat sangat diperlukan sebagai upaya untuk meningkatkan kualitas peternakan lele dengan penerapan teknologi yang bermanfaat. Peternakan lele memberikan aspek positif bagi peningkatan kualitas dan kemandirian ekonomi masyarakat.

Tri Herbaning Tiyas Wahyu Ningrum, Universitas PGRI Madiun triherbaningtiyaso9@gmail.com

Alvy Ervita Cahyany, Universitas PGRI Madiun alvyervita40@gmail.com

Tiara Meyna Anggraini, Universitas PGRI Madiun tiaraanggraini15@gmail.com

Wachidatul Linda Yuhanna, Universitas PGRI Madiun linda.yuhanna@unipma.ac.id 
Salah satu solusi untuk meningkatkan produktivitas peternakan lele adalah dengan mengintegrasikan pembudidayaan lele dengan hidroponik dengan sistem vertikal. Fokus penyelesaian masalah mitra adalah pada aspek teknologi yang digunakan. Vertiminaponik adalah budidaya sayuran secara vertikal dengan sistem akuaponik, dari satu tempat yang sama dapat menghasilkan dua komoditas sekaligus yaitu sayur dan ikan lele (Anwari et al., 2017) Vertiminaponik dapat dilakukan pada lahan sempit dan pekarangan rumah dengan hasil yang lebih optimal (Manganang \& Malupite, 2019). Sayuran hortikultura dapat secara mudah dibudidayakan bersama dengan kolam ikan lele.

Vertiminaponik merupakan jawaban dari permasalahan kekeringan dan menurunnya produksi sayuran. Penanaman sayuran yang dilakukan di atas kolam mampu memberi efektifitas pelaksanaan perikanan dan pertanian secara bersamaan (Sugeru et al., 2020). Keunggulan dari vertiminaponik (Dewi, 2014; Rokhmah et al., 2014) adalah 1) Hasil ikan dan sayuran dapat diperoleh sekaligus. Optimalisasi pekarangan sehingga menghasilkan sayuran dan protein dalam skala rumah tangga. Sayur dalam kondisi segar karena langsung dipetik dan pasti bersih karena kondisi dapat dikontrol sendiri. 2) Ikan lele yang dihasilkan juga dalam kondisi segar. 3) Hemat tempat dan tidak memerlukan lahan yang luas untuk bercocok tanam. 4) Tanaman hortikultura terjanin organik, karenatanaman hortikultura yang hidup tersebut mengkonsumsi kotoran ikan yang berenang dibawahnya. 5) Tanaman tidak perlu disiram setiap hari. Air yang dipompa akan terus menerus mengaliri tanaman penghias atau tanaman sayur. 6) Desain Vertiminaponik dapat disulap menjadi disain yang lebih menarik bagi penyuka desain taman dan pekarangan tergantung kreatifitas pengguna dengan memperhatikan nilai estetika .

Vertiminaponik adalah kombinasi antara akuakultur dengan hidroponik yang menghasilkan simbiosis mutualisme atau saling menguntungkan (Tustiyani \& Sinaga, 2018). Tanaman yang paling sering ditanam secara vertiminaponik, adalah tanaman-tanaman sayur. Sistem Akuaponik memiliki dua komponen penting, yaitu bagian hidroponik di mana tanaman tumbuh, dan bagian akuakultur di mana ikan dipelihara. Sistem vertiminaponik, budidaya sayuran secara vertikultur secara langsung akan didukung oleh sistem di bawahnya (Dewi, 2014; Rokhmah et al., 2014) Sistem di bawahnya yang merupakan tempat pemeliharaan ikan, menghasilkan sisa pakan dan kotoran ikan yang mengandung hara konsentrasi tinggi. Sedimen dari sistem akuatik seperti kotoran ikan dan pakan yang tidak dimakan dapat terakumulasi pada sistem pemeliharaan ikan yang tertutup dan tanpa sirkulasi (Rokhmah et al., 2020). Sedimen ini dapat menjadi racun bagi ikan pada konsentrasi tinggi, namun bernutrisi bagi tumbuhan.

Selain dua sistem utama di atas, akuaponik dapat memiliki sistem tambahan seperti biofilter yang menjadi tempat bagi bakteri nitrifikasi untuk mengubah amonia dari kotoran ikan menjadi nitrat yang dapat digunakan oleh tumbuhan, dan aerator yang mengirimkan udara ke air agar akar tumbuhan dapat bernafas. Tanaman ditumbuhkan di sistem hidroponik dengan akar mereka terendam dalam larutan penuh nutrisi (Sutrisna, 2020). Hal ini membuat tanaman mampu menyerap senyawa nitrogen yang dapat bersifat racun bagi ikan, sehingga akar berfungsi sebagai penyaring. Setelah air selesai melalui sistem hidroponik, air dibersihkan dai diaerasi sebelum kembali ke sistem akuakultur. 
Prinsip kerja dari vertiminaponik ini adalah dengan mengalirkan air secara terus menerus dengan menggunakan pompa akuarium dari kolam pemeliharaan ikan sebagai suplai hara bagi tanaman sayur (Noviani et al., 2020). Air dialirkan secara terus menerus dari bak penampungan ikan dengan menggunakan pompa akuarium. Air yang mengalir menuju tanaman sayur bercampur dengan kotoran ikan dan sisa pakan yang mengandung hara. Air tersebut dimanfaatkan unsur haranya oleh tanaman sayur, lalu kembali dialirkan ke bak ikan. Media tanam dan tanaman sayur yang berada diatas akan menyaring air dan mempertahankan kualitas air yang berada dibawahnya. Kondisi ini menyebabkan kualitas air kolam akan tetap terjaga dari sisa pakan dan kotoran ikan (Kustiani et al., 2019). Sehingga memberikan keuntungan bagi keduanya untuk pertumbuhan yang lebih baik dengan sistem yang berkelanjutan. Sistem vertiminaponik ini dapat menghasilkan sayuran dan ikan yang cukup banyak. Tujuan dari penelitian ini adalah mengembangkan sistem vertiminaponik untuk peternak lele.

\section{Metode}

Program ini dilakukan pada bulan Juni 2021. Program ini dilakukan di Universitas PGRI Madiun. Penelitian ini adalah penelitian pengembangan dengan menggunakan 4D (Define (pendefinisian), Design (perancangan), Develop (pengembangan) dan Disseminate (penyebaran). Instrumen yang digunakan adalah wawancara dan lembar validasi produk dari ahli. Validator terdiri dari akademisi dan praktisi. Data dianalisis secara deskriptif kualitatif dengan memperhatikan temuan yang terjadi selama proses perancangan alat. Instrumen pengukuran yang digunakan sebagaimana tabel 1 dan tabel 2.

Tabel 1. Instrumen wawancara pada proses define

\begin{tabular}{|c|c|c|}
\hline No. & Aspek & Pertanyaan \\
\hline \multirow[t]{3}{*}{1} & Permasalahan & $\begin{array}{l}\text { Bagaimana kinerja budidaya lele selama } 1 \text { tahun terakhir di } \\
\text { kelompok peternak lele Margo Rukun? }\end{array}$ \\
\hline & & $\begin{array}{l}\text { Permasalahan apa yang dihadapi oleh kelompok peternak lele } \\
\text { Margo Rukun? }\end{array}$ \\
\hline & & $\begin{array}{l}\text { Upaya apa yang selama ini sudah dilakukan untuk menghadapi } \\
\text { permasalahan? }\end{array}$ \\
\hline \multirow[t]{3}{*}{2} & Pengetahuan awal & $\begin{array}{l}\text { Apa yang Bapak/Ibu ketahui tentang hidroponik, aquaponik, } \\
\text { vertiminaponik? }\end{array}$ \\
\hline & & $\begin{array}{l}\text { Apa alat dan bahan dibutuhkan dalam membuat peralatan } \\
\text { tersebut? }\end{array}$ \\
\hline & & Bagaimana cara pembuatan alat tersebut? \\
\hline \multirow[t]{3}{*}{3} & Kebutuhan & $\begin{array}{l}\text { Apa yang dibutuhkan peternak lele untuk menjaga eksistensi } \\
\text { budidaya lele? }\end{array}$ \\
\hline & & $\begin{array}{l}\text { Bagaimana motivasi mitra dalam mewujudkan solusi dari } \\
\text { permasalahan? }\end{array}$ \\
\hline & & $\begin{array}{l}\text { Apakah peternak lele membutuhkan suatu bentuk bioteknologi } \\
\text { gabungan agribisnis? }\end{array}$ \\
\hline
\end{tabular}


Tabel 1. Instrumen lembar validasi produk pada proses development

\begin{tabular}{|c|c|c|c|c|c|c|}
\hline \multirow[t]{2}{*}{ No. } & \multirow[t]{2}{*}{ Aspek } & \multicolumn{5}{|c|}{ Jawaban } \\
\hline & & $\begin{array}{l}\text { Sangat } \\
\text { baik (5) }\end{array}$ & $\begin{array}{c}\text { Baik } \\
\text { (4) }\end{array}$ & $\begin{array}{l}\text { Netral } \\
(3)\end{array}$ & $\begin{array}{c}\text { Tidak } \\
\text { baik } \\
\text { (2) }\end{array}$ & $\begin{array}{c}\text { Sangat } \\
\text { tidak } \\
\text { baik (1) }\end{array}$ \\
\hline 1 & Desain produk vertiminaponik & & & & & \\
\hline 2 & $\begin{array}{l}\text { Keseuaian alat dan bahan pembuatan } \\
\text { vertiminaponik }\end{array}$ & & & & & \\
\hline 3 & Dimensi dan ukuran vertiminaponik & & & & & \\
\hline 4 & Tata letak rangkaian vertiminaponik & & & & & \\
\hline 5 & Ketahanan vertiminaponik & & & & & \\
\hline 6 & $\begin{array}{l}\text { Tingkat efisiensi biaya pembuatan } \\
\text { vertiminaponik }\end{array}$ & & & & & \\
\hline 7 & Kebermanfaatan produk pada mitra sasaran & & & & & \\
\hline 8 & $\begin{array}{l}\text { Potensi kemudahan mitra dalam menggunakan } \\
\text { vertiminaponik }\end{array}$ & & & & & \\
\hline
\end{tabular}

Tabel 3. Kriteria penilaian validasi produk

\begin{tabular}{llll}
\hline No. & Range Skor & Kategori & Keterangan \\
\hline 1 & $33-40$ & Sangat baik & Valid/ tanpa revisi \\
2 & $25-32$ & Baik & Valid/revisi \\
3 & $17-24$ & Cukup & Tidak Valid/Revisi \\
4 & $8-16$ & Kurang & Tidak valid/ diulangi \\
\hline
\end{tabular}

\section{Hasil dan Pembahasan}

Teknologi vertiminaponik dikembangkan di Universitas PGRI Madiun oleh tim Program Kreativitas Mahasiswa Penerapan IPTEK (PKM-PI) bersama dosen pendamping. Hasil teknologi ini siap untuk diimplementasikan kepada masyarakat sebagai upaya peningkatan produktivitas dan kesejahteraan peternak lele. Rancang teknologi ini dibuat dengan melalui tahapan sesuai pengembangan $4 \mathrm{D}$.

\section{Define (Pendefinisian)}

Tahapan pertama yang dilakukan adalah pendefinisian. Tahapan ini dimulai dari survey dan wawancara dengan kelompok peternak lele yang akan menjadi sasaran implementasi alat vertiminaponik. Tahapan ini digunakan untuk mengetahui sejauhmana kebutuhan dan pengetahuan awal kelompok sasaran terhadap teknologi yang akan dikembangkan. Hasil wawancara sebagaimana tabel 1.

Tabel 4. Hasil wawancara analisis pengetahuan awal dan kebutuhan

\begin{tabular}{llll}
\hline No. & Aspek & Pertanyaan & Jawaban \\
\hline 1 & Permasalahan & Bagaimana kinerja budidaya lele & Terjadi penurunan omset karena \\
& & selama 1 tahun terakhir di pandemi dan musim yang tidak \\
& & kelompok peternak lele Margo menentu. Terdapat 3 peternak lele
\end{tabular}




\begin{tabular}{|c|c|c|c|}
\hline & & Rukun? & yang gulung tikar. \\
\hline & & Permasalahan apa yang dihadapi & Pakan yang mahal. \\
\hline & & oleh kelompok peternak lele & Kondisi kolam sudah jelek \\
\hline & & margo rukun? & Harga jual tidak stabil \\
\hline & & & Produksi lele menurun \\
\hline & & Upaya apa yang selama ini sudah & Sebagian anggota kelompok \\
\hline & & dilakukan untuk menghadapi & bertahan, namun sebagian lagi \\
\hline & & permasalahan? & membiarkan kolam tidak terpakai. \\
\hline & & & Melakukan budidaya skala kecil. \\
\hline & & & Pakan membuat sendiri dari \\
\hline & & & bekatul. \\
\hline 2 & Pengetahuan & Apa yang Bapak/Ibu ketahui & Hidroponik bertanam sayur di \\
\hline & awal & tentang hidroponik,aquaponik, & pipa. Sayuran berupa kangkung \\
\hline & & vertiminaponik? & dan sawi. \\
\hline & & Apa alat dan bahan dibutuhkan & Pipa/paralon dan rak \\
\hline & & dalam membuat peralatan & \\
\hline & & tersebut? & \\
\hline & & $\begin{array}{l}\text { Bagaimana cara pembuatan alat } \\
\text { tersebut? }\end{array}$ & $\begin{array}{l}\text { Membuat rak, melubangi paralon, } \\
\text { meletakkan di atas rak. }\end{array}$ \\
\hline 3 & Kebutuhan & Apa yang dibutuhkan peternak & Kolam yang baik. air yang cukup. \\
\hline & & $\begin{array}{l}\text { lele untuk menjaga eksistensi } \\
\text { budidaya lele? }\end{array}$ & $\begin{array}{l}\text { Pakan yang cukup. Adanya } \\
\text { teknologi yang mendukung. }\end{array}$ \\
\hline & & Bagaimana motivasi mitra dalam & Sangat membutuhkan solusi dan \\
\hline & & $\begin{array}{l}\text { mewujudkan solusi dari } \\
\text { permasalahan? }\end{array}$ & $\begin{array}{l}\text { sangat antusias jika ada pelatihan } \\
\text { implementasi iptek. }\end{array}$ \\
\hline & & Apakah peternak & Sangat membutuhkan inovasi \\
\hline & & membutuhkan suatu bentuk & tersebut, dan sangat cocok \\
\hline & & bioteknologi gabungan & diterapkan. \\
\hline & & agribisnis? & \\
\hline
\end{tabular}

Berdasarkan tabel 4, dapat dilihat bahwa peternak lele Margo Rukun di Desa Wakah mengalami kendala yang terkait kondisi kolam, pakan, produksi dan harga jual lele. Terdapat kolam yang tidak terpakai. Padahal disatu sisi kolam ini dapat digunakans ebagai pendukung vertiminaponik. Aspek pengetahuan awal menujukkan bahwa peternak lele hanya mengetahui sistem aquaponik dengan sederhana. Peternak lele belum pernah mempraktekkan pembuatan aquaponik. Aspek kebutuhan dan motivasi, peternak lele sangat membutuhkan sentuhan bioteknologi yang dapat membantu dan mengangkat kembali perekomonian daris ektor agribisnis. Implementasi vertiminaponik dapat menopang ketahaman pangan dan stabilitas ekonomi di masa pandemi (Sutrisna, 2020). Vertiminaponik merupakan salah satu alternatif pertanian moderen sebagai solusi permasalahan pagngan dan ekonomi (Yuhanna et al., 2019).

\section{Design (Perancangan)}

Fokus pengembangan vertiminaponik adalah untuk menjawab permasalahan mitra kelompok peternak lele. Perancangan dimulai dari pengidentifikasian alat dan pembuatan produk. Secara umum alat yang digunakan dalam sistem vertiminaponik adalah bak penampung ikan, wadah, media tanam, aerator, pompa air, pipa PVC, selang, polibag, 
loyang, saringan, pot, dan holesaw. Bahan yang digunakan antara lain ikan, tanaman hortikultura, rockwool, nutrisi dan pakan ikan.

Cara pembuatannya terbagi menjadi 2 yaitu pembuatan kolam ikan dan pembuatan instalasi vertiminaponik. Untuk budidaya ikan dibutuhkan kolam, kolam bisa dibuat dari terpal, fiber atau semen/ tembok. Luas kolam dapat disesuaikan dengan kebutuhan budidaya tapi agar mudah dalam perawatan dan penempatan sebaiknya jangan terlalu luas contoh kita buat kolam $3 \times 4 \mathrm{~m}$ atau $2 \times 4 \mathrm{~m}$, dengan tinggi kolam minimal $60 \mathrm{~cm}$ sampai $110 \mathrm{~cm}$. Kolam jangan terlalu dangkal agar ikan lebih leluasa untuk bergerak sehingga perkembangannya akan lebih optimal. Setelah kolam terisi air kemudian nyalakan aerator yang ditempatkan didalam kolam selama kurang lebih 3 hari, aerator berfungsi untuk menambah oksigen didalam kolam. Setelah kolam siap kita sudah dapat menggunakan kolam untuk memelihara ikan. Ikan yang berada dikolam akan menghasilkan kotoran berupa bahan bahan organik yang sangat baik bagi tanaman. Untuk pemberian pakan dapat disesuakan dengan jenis ikan yang dipelihara. Pada umumnya ikan dapat diberimakan dua kali dalam sehari pada pagi dan sore hari. Jumlah ikan yang dipelihara dalam kolam harus sesuai dengan kebutuhan kotoran ikan yang akan digunakan untuk memupupuk tanaman.

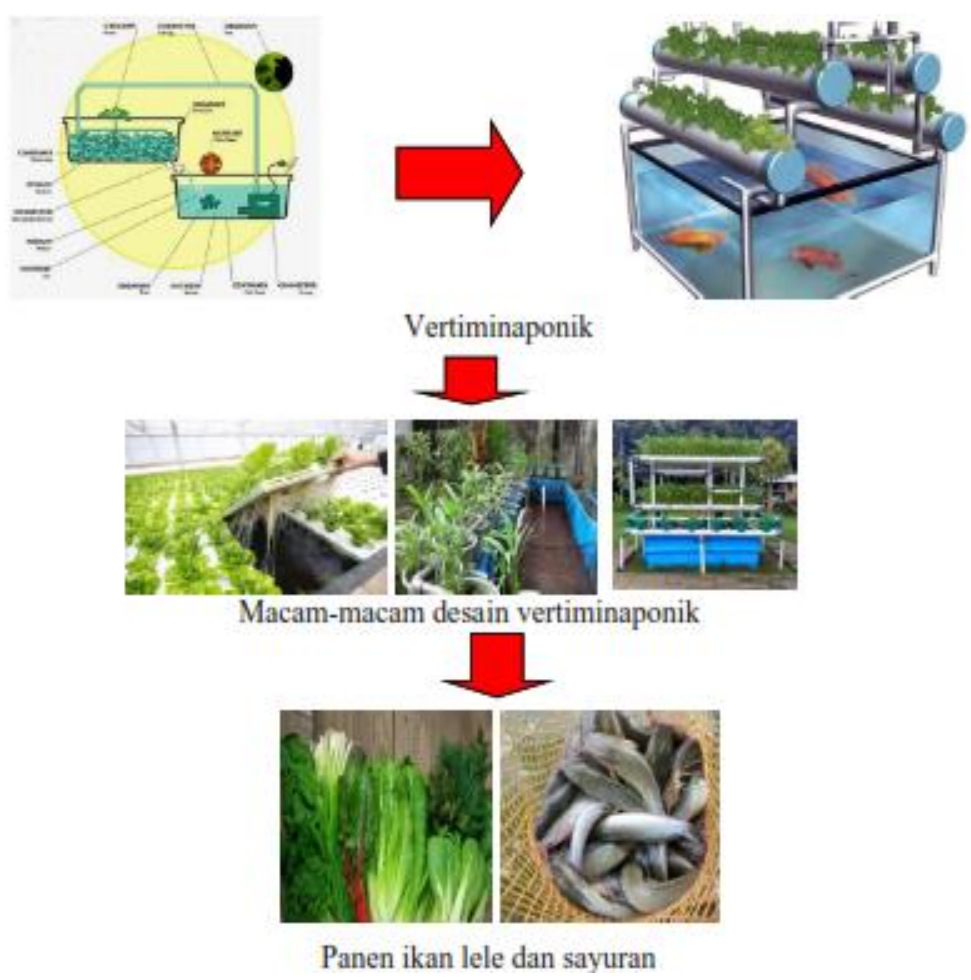

Gambar 1. Gambaran IPTEK berupa Vertiminaponik yang akan diterapkan

Pembuatan sistem penamaman dapat memulainya dari memotong pipa/ talang air dengan panjang disesuakan dengan kolam atau sesuakan selera anda. Setelah terpotong pipa diberi lubang menggunakan bor dengan diameter $5 \mathrm{~cm}$ (disesuaikan dengan netpot) dengan jarak antar lubang sekitar 15 sampai $20 \mathrm{~cm}$. Pada bagian salah satu ujung pipa bagian bawah diberi lubang dengan besar $1 / 2$ inchi kemudian potong pipa $1 / 2$ inci dengan 
panjang kurang lebih $30 \mathrm{~cm}$ kemudian tempatkan pada lubang. Penempatan pipa 1/2 inchi $5 \mathrm{~cm}$ berada di dalam pipa besar dengan posisi $25 \mathrm{~cm}$ berada di bawah kemudaian lem dengan kuat dan jangan sampai ada kebocoran.

Sedangkan pada salah satu ujung pipa beri lubang pada bagian atas dengan besar setengah sampai satu inchi fungsinya sebagai saluran air dari kolam menuju paralon. Tutup kedua lubang di ujung paralon dengan rapat. Paralon penanaman dapat ditempatkan di rak atau di atas kolam setelah itu pasang pipa dari penghubung pada pompa menuju pipa melalui lubang yang telah dibuat. Siapkan bibit tanaman kemudian masukkan kedalam tengah netpot kemudian masukkan media tanam sehingga tanaman akan berdiri tegak dan tidak mudah roboh. Setelah siap tempatkan netpot pada lubang lubang pipa yang telah dibuat. Setelah siap nyalakan pompa. Air dari kolam ikan akan mengalir melalui pipa 1/2 inchi kemudian akan memenuhi pipa 5 inchi dengan kedalaman kurang lebih $5 \mathrm{~cm}$ dan bila suadah penuh air akan terbuang melalui pipa pembuangan dan dialirkan menuju kolam ikan. Air yang mengalir ke kolam ikan akan lebih bersih karena kotoran kotoran tersaring dan di serap oleh tanaman.

\section{Develop (Pengembangan)}

Vertiminaponik yang dikembangkan merupakan modifikasi Teknik Film Nutrisi (NFT) menggunakan serangkaian pipa yang disusun berdekatan dengan tangki ikan (Mayasari et al., 2014). Dalam sistem ini, air kaya nutrisi dipompa ke dalam saluran tertutup (pipa) dengan arus yang sangat kecil. Sementara itu, tanaman diletakkan di pot plastik kecil dengan dasar berongga yang telah ditempatkan di lubang pipa sehingga memungkinkan akar untuk mengakses air dan menyerap nutrisi dari air yang mengalir perlahan di bawahnya. Hal yang perlu diperhatikan adalah hasil filtrasi harus bersih dari limbah padat.

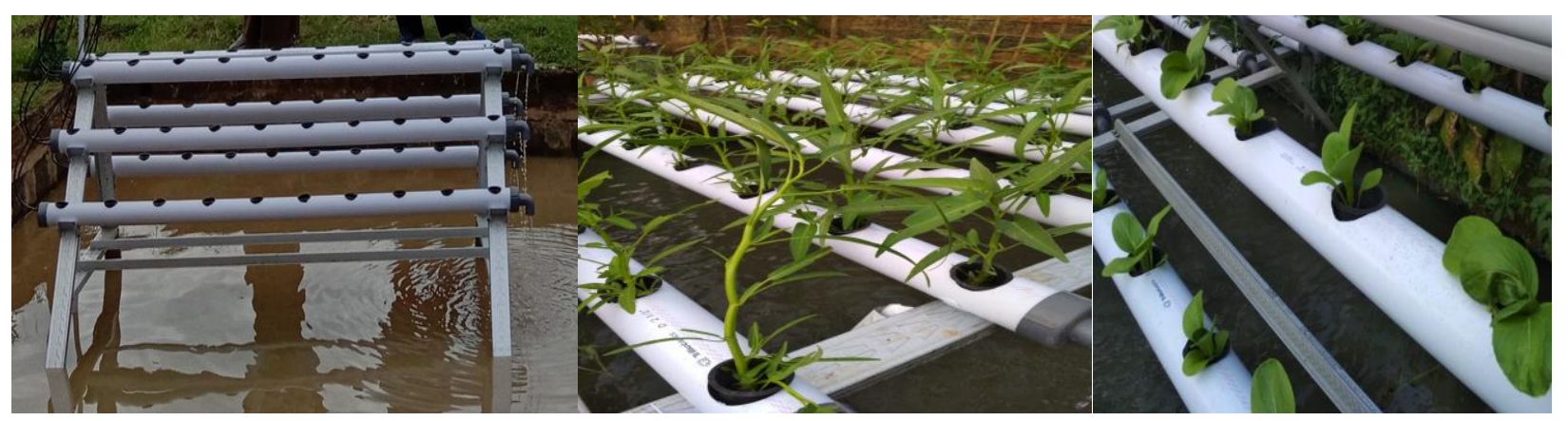

Gambar 2. Vertiminaponik untuk sayuran kangkung dan sawi

Keunggulannya adalah 1) Sistem terbaik untuk aquaponik skala besar, umum digunakan di hidroponik, 2) Sangat efisien dalam penggunaan air, 3) Susunan tanaman terlihat rapi dan tertata, 4) Paling hemat tempat, dapat dibuat vertikal. Tahapan ini, tim juga memberikan lembar validasi produk dari ahli akademisi dan praktisi. Hasil penilaian produk rancang alat ini disajikan pada tabel 5 berikut 
Tabel 5. Hasil observasi penilaian produk vertiminaponik oleh akademisi dan praktisi

\begin{tabular}{|c|c|c|c|c|}
\hline \multirow[t]{2}{*}{ No. } & \multirow[t]{2}{*}{ Aspek } & \multirow{2}{*}{$\begin{array}{c}\text { Skor } \\
\text { maksimal }\end{array}$} & \multicolumn{2}{|c|}{ Penialian Ahli } \\
\hline & & & Akademisi & Praktisi \\
\hline 1 & Desain produk vertiminaponik & 5 & 4 & 5 \\
\hline 2 & $\begin{array}{l}\text { Keseuaian alat dan bahan pembuatan } \\
\text { vertiminaponik }\end{array}$ & 5 & 4 & 5 \\
\hline 3 & Dimensi dan ukuran vertiminaponik & 5 & 5 & 5 \\
\hline 4 & Tata letak rangkaian vertiminaponik & 5 & 5 & 5 \\
\hline 5 & Ketahanan vertiminaponik & 5 & 5 & 5 \\
\hline 6 & $\begin{array}{l}\text { Tingkat efisiensi biaya pembuatan } \\
\text { vertiminaponik }\end{array}$ & 5 & 4 & 4 \\
\hline 7 & Kebermanfaatan produk pada mitra sasaran & 5 & 5 & 5 \\
\hline 8 & $\begin{array}{l}\text { Potensi kemudahan mitra dalam menggunakan } \\
\text { vertiminaponik }\end{array}$ & 5 & 5 & 4 \\
\hline & Skor maksimal & 40 & 37 & 38 \\
\hline
\end{tabular}

Berdasarkan data tabel 5 dapat diketahui bahwa skor validasi yang diberikan oleh validator dari unsur akademisi sebanyak 37 dan skor dari praktisi adalah 38. Sesuai dengan kriteria di tabel 3, maka hasil rancang bangun vertiminaponik ini dalam kategori sangat baik sehingga layak dan tanpa revisi untuk diimplementasikan kepada kelompok sasaran. Vertiminaponik dapat dilakukan dan dikerjakans ecara mandiri dengan alat bahan yang sederhana dan mudah ditemui (Yuhanna et al., 2019). Adanya rancang bangun alat tertentu, harus melalui tahapan pengembangan yang utuh. Sehingga masyarakat akan lebih yakin dalam menerapkan teknologi.

\section{Disseminate (Penyebaran)}

Proses disseminate akan dilakukan skala kecil ke peternak lele Margo Rukun. Selama pandemi, proses disseminate akan dilakukan terbatas dan sesuai protokol kesehatan lengkap. Persiapan program dilakukan dengan melakukan Focus Group Discussion (FGD) dengan kelompok mitra sasaran. Pembuatan vertiminaponik dilakukan dengan memperhatikan bentuk kolam, kondisi kolam dan tanaman yang akan dibuat vertiminaponik. Sistem vertiminaponik yang dikembangkan adalah sistem Deep Water Culture (DWC) dan Nutrien Film Technique (NFT) secara bertingkat. Kedua sistem tersebut mempunyai spesifikasi dan keunggulan masing-masing. Berdasarkan proses disseminate pada 5 orang peternak lele, mereka menyatakan siap menerima teknologi dan berkomitmen untuk mengembangkannya. Proses selanjutnya adalah implementasi kepada kelompok peternak lele Margo Rukun secara keseluruhan.

\section{Simpulan}

Simpulan dari penelitian ini adalah pengembangan vertiminaponik berhasil dilakukan dengan menggunakan metode 4D. Vertiminaponik yang dikembangkan merupakan modifikasi Teknik Film Nutrisi (NFT) menggunakan serangkaian pipa yang disusun berdekatan dengan tangki ikan. penilaian validator dari unsur akademisi dan praktisi, 
produk vertiminaponik dalam kategori sangat baik sehingga layak dan tanpa revisi untuk diimplementasikan kepada kelompok sasaran.

\section{Ucapan Terima Kasih}

Penulis menyampaikan terima kasih kepada Belmawa Kemdikbudristek yang telah mendukung kegiatan ini melalui skim pendaaan PKM-PI. Penulis juga menyampaiakn terimakasih kepada Universitas PGRI Madiun dan kelompok peternak lele Margo Rukun Desa Wakah Kecamatan Ngrambe Kabupaten Ngawi sebagai mitra dalam kegiatan ini.

\section{Daftar Rujukan}

Anwari, K., Hasaka, D. R., \& Hindun, H. N. (2017). Taman Produktif Masyarakat dengan Vertical Garden by Aquaponik System (Vgas) Berbasis Distribusi Terkendali di Kampung Code Yogyakarta. Jurnal Ilmiah Penelitian Dan Penalaran Mahasiswa, 1(1), 23 32.

Dewi, A. N. (2014). Vertiminaponik Sebagai Modal Ekonomi Masyarakat Kampung Sewu. 17-28.

Kustiani, I., Irianti, L., \& Purba, A. (2019). Pemberdayaan kelompok tani kampung agrowidya wisata sinar harapan melalui pelatihan teknologi vertiminaponik pendukung pertanian perkotaan. Journal of Empowerment., 2(2).

Manganang, J., \& Malupite. (2019). Ketahanan Pangan the Use of the Plot of Land With the Concept of Minahorticulture and Vertiminaponik for Food Stock in. Jurnal Ilmiah Tatengkorang, 3(2), 72-75.

Mayasari, K., Ammatillah, C. S., \& Sastro, Y. (2014). Persepsi pengguna teknologi vertiminaponik (Studi Kasus Kelompok Tani Jati Songo, Jakarta Timur). 4, 23-29.

Noviani, N. E., Nugraheni, S. S., \& Ika, A. (2020). Sosialisasi dan Pembibitan Kebun Gizi Vertiminaponik untuk Meningkatkan Ketahanan Pangan di Desa Tuksono, Sentolo, Kulon Progo. University Research Colloquium, 171-176.

Rokhmah, N. A., Rahman, M., \& Sastro, Y. (2020). Reduksi Amonia Oleh Kangkung Darat (Ipomea Reptans) Pada Budidaya Ikan Menggunakan Teknologi Vertiminaponik. 33-41. https://doi.org/10.25047/agropross.2020.9

Rokhmah, N. A., Soraya Ammatillah, C., \& Sastro, Y. (2014). Nofi A. Rokhmah et. al.: Vertiminaponik, Mini Akuaponik untuk Lahan Sempit di Perkotaan. Buletin Pertanian Perkotaan, 4(30), 14. http://jakarta.litbang.pertanian.go.id/ind/artikel bptp/buletin vertiminaponik vol4 no.2 2014.pdf

Sugeru, H., Musa, P., \& Miska, M. E. E. (2020). Design and implementation of ecoholistic vertiminaponic with automated control and internet of things based monitoring system for sustainable urban farming. IOP Conference Series: Earth and Environmental Science, 457(1). https://doi.org/10.1088/1755-1315/457/1/012063

Sutrisna, N. (2020). Urban Agricultural Development For Food Security At The Time Of Covid-19 Pandemies In Indonesia. 4(2), 165-172.

Tustiyani, I., \& Sinaga, V. R. (2018). Sosialisasi sistem vertiminaponik di desa cidatar kecamatan cisurupan, kabupaten garut. Jurnal Pengabdian Dan Pemberdayaan Masyarakat, 2(2).

Yuhanna, W. L., Sulistyarsi, A., \& Widiyanto, J. (2019). Peningkatan Jiwa Kewirausahaan Mahasiswa Melalui Vertiminaponik. Jurnal Abdimas Madani Dan Lestari (JAMALI), 1(2), 105-113. https:/ / doi.org/10.20885/jamali.vol1.iss2.art6 